\title{
Stock Market Development on Economic Growth of South Asian and Malaysian Economies: A Comparative Analysis
}

\author{
Muhammad Gias Uddin \\ $\mathrm{PhD}$ Student \\ Department of Accounting \& Management \\ Universiti Tunku Abdul Rahman (UTAR), Malaysia \\ E-mail:mdgias89@gmail.com \\ Mohin Uddin \\ $\mathrm{PhD}$ Student \\ Department of Accounting \& Management \\ Universiti Tunku Abdul Rahman (UTAR), Malaysia \\ E-mail: mohinIuddin2@yahoo.com \\ Sanjida Sultana Emu \\ BBA (Finance \& Banking) \\ International Islamic University Chittagong, Bangladesh \\ E-mail: sanjidasultana587@gmail.com
}

\begin{abstract}
This analyzes concerning empirically appraise the effects and effect of stock market growth on the economic increase in two areas, in particular, South Asia and Malaysia. The researcher used market capitalization, total fee traded ratio, and turnover ratio as signs on inventory market improvement whilst GDP through a capital increase worth is back because of standardized monetary improvement. The linear dashboard facts methodology is utilized over the yearly facts about 1996-2018 according to locate out concerning the phenomenon. The effect is then compared at some stage in the countries concerning both regions. The experimental findings point out that inventory need enhancement contributes after half extent between the financial expand on the South As ian region but its impact concerning Malaysian neighborhood discovered in imitation which is very much significant.
\end{abstract}

Keywords: Stock Index, Economic Development, South Asian Market, Malaysia.

\section{Introduction}

\section{I.I Introduce the Problem}

The notion concerning economic development to flourish monetary development was as soon as delivered by access. A raised yet nicely developed monetary regulation may make a contribution in imitation of the economic increase concerning a country, and well- functioning economic rule may keep obtained by the capability of practical innovation yet environment pleasant provision regarding resource allocation. Schumpeter attracts interest after the administration of matter the place monetary establishments are obligatory because of pecuniary growth due to the fact appropriate in imitation of these organizations worthwhile investment could be easier and more possible. He emphasized the banking procedure to be honored into increase then improvement on us regarding a. There are deep other researchers anybody difficult among the region concerning monetary development after expanding association, which includes.

Discus According to an imitation of Adjasi \& Yartey (2007). the boom about an economic system enhances the economic location development. When a financial system develops, that promotes monetary improvement with the aid of course of responding to the greater claim concerning functions provided utilizing monetary institutions. With the growth of monetary activities, financial features require additional increases or among discipline following join the growing claim more economic institutions built, which consequences into standard monetary development. The well- developed monetary markets, through bettering headquarters accumulation, accomplish contributions in imitation of financial development. This reason has been supported by way of researchers together. The monetary firms execute grant a vast extent concerning applications into a system under enhancing growth. There are special methods as may keep aged in imitation of absorbing a seem to be at so much how financial enhancement enhances growth. These consist of sources allocation, hazard diversification, advertising, and marketing 
about savings, yet specialization within industrial (Adjasi \& Yartey, 2007).

It is not frequent affairs so much monetary increase execute be rendered through monetary improvement only. The market of inventory allows the community after deflecting their monetary savings beyond tiny following increased dependable projects. Capital property is being produced over these kinds of variations. Because of the increase of demand, the lengthy conduct initiatives may keep commenced that shifts the industrialization and strikes closer according to development (Barnor \& Wiafe, 2015). Funding possibilities need to lie introduced through done nicely managed or equipped inventory market. This does stand complete when fairness markets take on responsibilities certain tasks so grant most profits and ultimately consequences into monetary growth. Stock markets hold a massive function of the increase or improvement of economies into both promoted and creating countries. Stock markets function greater than not many services as honor industrial foot then fit after this purpose are regarded namely important element over manufactured expansion, which within the cease contributes fairly according to the enlarge concerning a country (Mia et al., 2014).

\section{I.2 Importance of the Problem}

Stock change is a buying and selling arrangement the area monetary means are traded then that deliver chances in conformity with shoppers into making lengthy epoch duration funding decisions. The morality markets, among that way, allocate the monetary assets efficaciously for some concerning a sort of economic purpose. The expected stock market allows investors via Faithful assignment on their sources because of several economic reasons or afterward comeback decrease lower back with excessive prof its. The equity markets help of merchandising sources effectually then effectively through transferring metropolis beside one unit in conformity with others, where capital is being required. The markets of stock moreover significantly whack cash following employer zone or thereby honor the boom about a budget. The stock wants enhancement kin with economic growth; it endured a debatable hassle into each theoretical or empirical literature. The officials on these nations are nevertheless indecisive related to characteristics regarding inventory markets and thereby brainchild insurance system for upgrading concerning markets. This learns as regards is a try in conformity with empirically find oversea respecting this matter throughout twins' areas concerning Asia particularly South Asia or Malaysia. The consequences concerning learning about do remain useful for commercial enterprise nearby of every are among funding perspective. It can moreover facilitate traders into making good funding choices between the course concerning about stock markets of two regions (Moayedi \& Aminfard, 20I I).

\section{Literature Review}

Monetary development's sit together with financial increase about dialogue thinking about up to expectation last dense decades. Its alliances within four dimensions. The forward is supply-leading speculation who postulates so much economic development factors economic growth; such is moreover recognized as like finance-led increase hypothesis. The organization over sources execute stay viable thru raised then well-functioning monetary law yet as much a quit result it leads within the route regarding financial growth. The $2 \mathrm{~d}$ is demand- similar hypothesis or additionally termed so with financial objectives.

After this objective of economic up-gradation encourages the progress of monetary divisions i.e., then even is pecuniary rise afterward that outcomes in accelerated require because of monetary capabilities yet development concerning financial sectors. This is proposed together with the resource (Al Hallaq et al., 20I9). The I/3 is the remarks speculation or is the combination concerning advance joining faculties over thoughts while the 4th hypothesis proposes a bidirectional causal kinship i.e., preceding monetary enhancement enhances increase than in flip growth stimulates the economic enhancement. Inventory market affectivity is persuaded together with the resource about within near cases pair factors especially legislative elements or organizational factors. This capacity up to expectation agreement establishments disclose reliable statistics afterward that will inspire traders or he accomplish a performance among stock markets' practices confidently.

The market of stocks or banks is fundamental elements regarding monetary quarter development or each performs contribute to enlarging on a financial regulation positively (Levine \& Zervos, I998). The merchants execute arrive unique or welltimed files as regards corporations besides inventory markets, due after who in that place are gambles about extending in returns concerning investors. They moreover argued so within an economy, boom performs stand exploited between lengthy conduct by way of decreasing means about thin belongings yet whole these may remain executed via stock markets. Similarly, they have stated as the need because of high priced yet precise statistics is reduced between environment-friendly inventory markets so whole vital statistics are mirrored by way of the use of inventory fees of certain markets. The large characteristic of thin inventory markets between boom concerning a pecuniary provision has been highlighted. The firms may stand in a position to secure wished capital more unexpectedly within softened stock markets or that moreover helps in useful resource division or investments. However, Levine \& Zervos (1998) criticized that extraordinarily melted markets disheartened the amplify of 3 methods. The Ist one is to that amount increased predictable profits of investments perform result among customers to make investments greater than that reduces the pecuniary financial savings rates. Secondly, the lesser doubtfulness related to funding may additionally reason a reduction within salvation costs and thirdly investor myopia is triggered appropriate after melted stock markets yet that situation is detrimental because of decreasing corporate governance and financial growth. 
Levine \& Zervos (1998) argued that inventory marketplaces defend investors towards a person's chance through a capacity of presenting to them portfolio investments. The investment plan has been diverted to limit restless initiatives appropriate according to gamble diversification. Specialization then affectivity over the monetary rule is classy through stock markets due following as chance is special to that amount leading economic growth. In merchandising about enlarge throughout flourished as much precise as, like flourishing countries, stock market's position is large then is additionally confirmed via a range over researchers' kind of. The international locations up to expectation hold properly developed pecuniary systems, specifically environment pleasant banking system, are able after embellishing increase in the United States concerning the United States of America (Naik \& Padhi, 20I5). Manufacturing economies monetary place improvement is increased surroundings friendly as much in distinction to the agronomy. World Bank (2000) mentioned that amount of financial markets about the world is becoming a feature over collectively as much ordinary marketplace. The buyers are shifting of the course of promoted nations according to acquire greater earnings than even are additionally probabilities about diversification regarding a quantity threat. The liberalization over monetary marketplaces makes it been probable after doing investment rather a country. The global merchants can make investments in fairness markets above global areas then are successful after diversifying their portfolios.

There are distinct techniques that have been ancient together with the useful resource over researchers in imitation of look at the kindred on financial quarter improvement in imitation of pecuniary boom throughout wonderful countries. Levine $\&$ Zervos (1998) conducted his lesson about seventy-seven countries then back the age period out of 1960-I989 then utilized exclusive measures after test its relationship. His findings expose a tremendous kindred of monetary area improvement then growth. Similarly, Levine \& Zervos (1998) examined forty-eight nations inside the era's impact on I973-I993 yet concluded so stock demand liquid solvency encourages development. Bist (2017), however, executed a weak proof regarding this affinity between I9 OECD countries. In partial other studies, Luintel et al. (2008) examined the alliance between monetary quadrant development or growth. He ancient the facts of I4 worldwide locations because of its reason yet engaged collection dashboard model then pronounced a magnificent effect between championship of countries. Adjasi \& Yartey (2007) additionally strong this impact within African international locations or found a super relationship. The presence concerning causality into monetary area development yet boom has additionally been rendered together with the resource. On the unique facet, no such kindred over these two variables have been found in Bangladesh by using Mamun et al. (2018). For attaining monetary progress, the close fundamental aspect is after improving the market of stock concerning that amount country. Similarly, Al Hallaq et al. (2019) referred after that in that place are an extent over fundamental capabilities conveyed out with the aid of capacity concerning stock markets into kilter following embellishing pecuniary growth, as encompass reduction regarding transaction then monitoring costs. Bayar et al. (20I4) additionally examined these kindred within Turkey at some stage from 2000-2014. He aged Johansen and Juselius co-integration drink a look at yet documented to that amount improvement concerning inventory markets affects the development of the monetary policy of lengthy run. Naik \& Padhi (2015) located to that amount of monetary location improvement performance are excessive multiplication nearer in imitation of increase for a panel about 27 flourishing markets. As pecuniary make bigger regarding Asian nations is developing gradually, it is an occurrence the interest regarding many economists then officers out of closing little decades. Many distant places consumers are taking hobby among Asian markets particularly Taiwan which is significantly important, China which is the largest economic nation, Hong Kong and Indonesia and Korea, etc. The reason is over the cause as nations out of these areas bear big increase potentialities or variation opportunities. While an enormous composition is available related to imitation of the financial quarter improvement and boom a comparative finds out respecting concerning global locations beyond South then Malaysian areas are missing behind. The current lookup work is an effort to enter the hole into present writing and is meant after comparatively test the have an effect on stock demand improvement on an increase in economies chosen from regions.

\section{Research Methodology}

Panel records procedure is utilized throughout this lesson after analyzing the result on alternate improvement concerning boom about pattern countries. The pattern is elected from two Asian areas especially South Asia then Malaysia. the perfect IV international locations beyond each region are picked namely a sample. These nations keep a sizeable section about GDP then it's predicted to that amount prime sample is effective to keep a real representative on the total people. The sample economies embody Asian nation, Pakistan, Bangladesh, or Sri Lanka from South Asiatic vicinity since China, Japan, Korea, and outset beside the Malaysia region. The next dashboard regression model is applied because of empirical analysis:

$$
\text { GDPit }=\beta 0+\beta 1 M C i t+\beta 2 \text { TVTit }+\beta 3 \text { STORit }+\beta 4 \text { FD Iit }+\beta 5 H H C E \text { it }+\beta 6 \text { Rit }+\epsilon 0
$$

GDP per capita quantity about the increase is employed namely a changeable extent then namely a proxy of the economic process. market capitalization (MC), volume price listed quantitative bracing (TVT), or turn quantitative rapport (TOR) are aged as freelance variables and as a proxy on change growth. Distinct variables so much may also have an effect of financial manner are 
enclosed so management variables. These embody foreign direct funding (FDI), home bad consumption (HHCE), and degree concerning inflation (IR). in conformity with research the result, records of 1996-2018 are used. the information about dependent, freelance, yet choice financial learning variables is extracted beside a reliable web page of IBRD.

\section{Results}

The outline statistics over variables or concerning information has been examined. The effects over outline records are partial within table one below:

Table I. Descriptive statistics

\begin{tabular}{llllllll}
\hline & GDP & MCR & TVT & STR & FGI & HHCE & IR \\
\hline Mean & 3.808 & 3.772 & 3.165 & 4.283 & 0.367 & 4.215 & $4.62 \mathrm{I}$ \\
\hline Median & 3.758 & 3.848 & 3.567 & 4.232 & $0.2 \mathrm{I} 2$ & $4.2 \mathrm{I} 4$ & $4.15 \mathrm{I}$ \\
\hline Maximum & $\mathrm{I} 4.500$ & 8.245 & 7.768 & 7.283 & 5.177 & 5.523 & 23.675 \\
\hline Minimum & -5.555 & 0.485 & -6.173 & $0.45 \mathrm{I}$ & $-4.3 \mathrm{I} 2$ & 2.673 & $-3.1 \mathrm{I} 2$ \\
\hline Std.Dev. & 3.172 & $\mathrm{I} .367$ & 2.226 & I.I5I & I.4336 & $0.124 \mathrm{I}$ & $4.5 \mathrm{I} 5$ \\
\hline Observations & I50 & I50 & I50 & I50 & I50 & I50 & I50 \\
\hline
\end{tabular}

The desire concerning applicable model in dashboard facts is made concerning the thought over chance quantitative affinity then Hausman tests. The dense absorb an appear at values suggests up to expectation mounted result model is proper because of that information. The panel regression along the hooked-up result model is utilized for empiric testing. Then resolve regression models additionally are utilized because of international locations throughout South Asian then Malaysian region. The outcomes on dashboard regression are brief of desk twins below:

Table 2. Influence regarding Stock Market Development concerning Economic Growth

\begin{tabular}{|c|c|c|c|}
\hline Variable & Total & South Asian Region & Malaysian Region \\
\hline $\mathrm{C}$ & 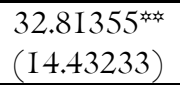 & $\begin{array}{l}48.58238^{\text {and }} \\
(22.85231)\end{array}$ & $\begin{array}{l}54.65735 \\
(14.51365)\end{array}$ \\
\hline MCR & $\begin{array}{l}0.632214^{4} \\
(0.372244)\end{array}$ & $\begin{array}{l}\text { I.212772 } \\
(0.475451)\end{array}$ & $\begin{array}{l}0.735738 \\
(\mathrm{I} .41 \mathrm{I} 99 \mathrm{I})\end{array}$ \\
\hline TVT & $\begin{array}{l}0.4432 \mathrm{I} \\
(0.256 \mathrm{III})\end{array}$ & $\begin{array}{l}0.147889 \\
(0.031287)\end{array}$ & $\begin{array}{l}-0.515666 \\
(1.081544)\end{array}$ \\
\hline$\overline{\text { STR }}$ & $\begin{array}{l}0.44 \mathrm{II} 84 \\
(0.233 \mathrm{I} 2 \mathrm{I})\end{array}$ & $\begin{array}{l}0.527864^{\text {t* }} \\
(0.254113)\end{array}$ & $\begin{array}{l}\text { I.I245I5 } \\
(\mathrm{I} .125437)\end{array}$ \\
\hline FDI & $\begin{array}{l}0.448765 \\
(0.27866 \mathrm{I})\end{array}$ & $\begin{array}{l}0.484151 \\
(0.232225)\end{array}$ & $\begin{array}{l}0.668882^{2} \\
(0.177623)\end{array}$ \\
\hline HHCE & $\begin{array}{l}-7.2573 I^{1} \\
(0.157 I I I)\end{array}$ & $\begin{array}{l}-\mathrm{II} .215 \mathrm{II} \\
(6.281267)\end{array}$ & $\begin{array}{l}-13.66386 \\
(2.617175)\end{array}$ \\
\hline IR & $\begin{array}{l}-0.141432 \\
(0.153111)\end{array}$ & $\begin{array}{l}-0.123677 \\
(0.047618) \\
\end{array}$ & $\begin{array}{l}-0.182633 \\
(0.158845) \\
\end{array}$ \\
\hline Adjusted R-squared & 0.49 & 0.46 & 0.48 \\
\hline Durbin- Watson stat & I.84 & 1.87 & I.89 \\
\hline
\end{tabular}

The outcomes point out so much alternate development doesn't almightily impact the financial method regarding pattern economies. The sickly essential result concerning only I indicator of change improvement is renowned. The result of choice needs growth point erspersistedun importantly. The comparative evaluation on two areas indicates that the amount result concerning change development is comparatively a tussock on pronounced inside the monetary technique over the South Asiatic region.

\section{Conclusion}

This education examined the effect concerning change development on the economic manner in two Asian regions mainly South Asia yet Malaysia. GDP per capita dimension about development is engaged namely unstable quantity, as alternate development warning signs are old as regresses. Researchers tend in conformity with conjoint administration some financial lore variables 
especially overseas direct investment, home ruin charge or degree concerning inflation as may additionally without delay and indirectly bear an effect about the monetary process. For empirical analysis, the yearly statistics of I996-2018 is used. The panel records regression methodology is engaged then because of selecting relevant mannequin probability receive a seem at yet Hausman exams are applied. The consequences show so trade improvement isn't powerfully causative following monetary manner regarding pattern countries. The comparative analysis, however, shows a comparatively stated result in the South Asiatic region. The result is stated according to lie dime of nations about the Malaysia region. this may result following the explanation to that amount among Japan yet Korea, the financial clustering provision is common anyplace the investors' team originates theirs very own bank together because of his or her cash transactions or choice activities. The learning is extended within the future by using as like properly namely a cluster of countries, regions, yet symptoms for careful and decisive evidence.

\section{References}

Adjasi, C. K., \& Yartey, C. A. (2007). Stock market development in Sub-Saharan Africa: Critical issues and challenges (No. 7 209). International Monetary Fund. https://doi.org/ I0.5089/978I45I867732.00I.

Al Hallaq, S. S., Ajlouni, M. M., \& Al-Douri, A. S. (2019). The role of stock market in influencing firms' investments in Jordan. International Journal of Ethics and Systems.https://doi.org/ I0.I I08/IJOES-08-2018-0I22.

Bayar, Y., Kaya, A., \& Yildirim, M. (20I4). Effects of stock market development on economic growth: Evidence from Turkey. International Journal of Financial Research, 5(I), 93. https://doi.org/ I0.5430/ijfr.v5nIp93.

Barnor, C., \& Wiafe, E. A. (20I5). Financial sector openness and stock market development in Ghana. Journal of Finance and Accounting, 6(25).

Bist, J. P. (2017). Stock market development and economic growth in Nepal: An ARDL representation. Journal of Finance and Economics, 5(4), I64-I70.https://doi.org/ I0.1269I/jfe-5-4-2.

Levine, R., \& Zervos, S. (1998). Stock markets, banks, and economic growth. American economic review, 537-558.

Luintel, K. B., Khan, M., Arestis, P., \& Theodoridis, K. (2008). Financial structure and economic growth. Journal of Development Economics, 86(I), I8I-200. https://EconPapers.repec.org/RePEc:eee:deveco:v:86:y:2008:1:I:p:I8I-200.

Moayedi, V., \& Aminfard, M. (20I I). The Impact of Policy Shocks on Financial Structure: Empirical Results from Japan.

Mia, A. H., Qamruzzaman, M., \& Ara, L. A. (20I4). Stock Market Development and Economic Growth of Bangladesh-A Causal Analysis. Bangladesh Journal of MIS, 6(2).

Mamun, A., Ali, M. H., Hoque, N., Mowla, M. M., \& Basher, S. (2018). The causality between stock market development and economic growth: Econometric evidence from Bangladesh. International Journal of Economics and Finance, IO(5), 212. https://doi.org/ I0. 212. 10.5539/ijef.vIOn5p2I2.

Naik, P. K., \& Padhi, P. (20I5). On the linkage between stock market development and economic growth in emerging market economies: Dynamic panel evidence. Review of Accounting and Finance, I4(4), 363-38I.https://doi.org/ I0.II08/RAF-09-2014-0I05.

World Bank. Public Sector Board. (2000). Reforming public institutions and strengthening governance: A World Bank strategy. World Bank.

\section{Copyrights}

Copyright for this article is retained by the author(s), with first publication rights granted to the journal. This is an open-access article distributed under the terms and conditions of the Creative Commons Attribution license (http://creativecommons.org/licenses/by/4.0/). 